\title{
ReSEARChArticle
}

\section{Performance of different mustard varieties in Terai zone of West Bengal}

\author{
Pranab Barma, Hriday Kamal Tarafder, Ramkrishna Sarkar and M.W. Moktan
}

\section{SUMMARY}

The research on varietal screening for a specific location has done since long time. But varietal screening of Indian mustard at Terai region has meagre hitherto. Therefore, an experiment was performed to evaluate the performance of different mustard varieties in Regional Research Sub-Station (Terai Zone), Uttar Banga Krishi Viswavidyalaya in the year 2015-16 during Rabi season (Dec.- Feb.). The study was purposively done to evaluate five mustard varieties viz., T-9, Piloo, NC-1, PS-28 and B-9 in Terai Zone of West Bengal with respect to yield attributing characters. In brevity it was found that Pilloo is most suitable cultivar for studied areas.

Key Words : Mustard varieties, Yield attributing characters

How to cite this article : Barma, Pranab, Tarafder, Hriday Kamal, Sarkar, Ramkrishna and Moktan, M.W. (2021). Performance of different mustard varieties in Terai zone of West Bengal. Internat. J. Plant Sci., 16 (1): 31-33, DOI: 10.15740/HAS/IJPS/16.1/31-33, Copyright@ 2021: Hind Agri-Horticultural Society.

Article chronicle : Received : 05.09.2020; Revised : 07.11.2020; Accepted : 08.12.2020

\footnotetext{
$\longrightarrow$ MEMBERS OF THE RESEARCH FORUM

Author to be contacted :

Pranab Barma, Darjeeling Krishi Vigyan Kendra, Uttar Banga Krishi

Viswavidyalaya, Kalimpong (W.B.) India

Email : pranab.barma@gmail.com
}

Address of the Co-authors:

Hriday Kamal Tarafder, Regional Research Station, Uttar Banga Krishi Viswavidyalaya, Kalimpong (W.B.) India

Ramkrishna Sarkar, Regional Research Sub-Station, Terai Zone, Uttar Banga Krishi Viswavidyalaya, Kharibari, Darjeeling (W.B.) India

M.W. Moktan, Darjeeling Krishi Vigyan Kendra, Uttar Banga Krishi Viswavidyalaya, Kalimpong (W.B.) India 